\title{
The implications of E Schillebeeckx's theology of liberation for anthropology and creation
}

D J Malan

\section{ABSTRACT}

The implications of E Schillebeeckx's theology of liberation for anthropology and creation

The theology of Edward Schillebeeckx has direct relevance for the situation of violence in South Africa Anthropology and creation are closely linked in his theology through Christology. Christology is "concentrated creation". It underscores the grace of God as well as the responsibility of man. The negative contrast experiences of humanity calls for decisive praxis. Praxis is the precursor of theology and the function of theology is to ascertain whether the praxis of the church is secundam scripturas. His liberation theology helps to analyse underlying ideologies which are detrimental to human wellbeing. His theology cautions us not to identify too easily with one or the other party or class, because the Name of God can be misused by oppressors as well as freedom fighters.

THESIS

The thesis of this article is that the theology of prof Edward Schillebeeckx of Nijmegen has direct implications for anthropology and the integrity of creation which is highly relevant to our South African context ${ }^{1}$.

The problems with which this thesis confronts us, are: Why does Schillebeeckx call his theology a theology of liberation? What roles do anthropology and creation play in his systematic biblical approach? What are the implications of his theology for our situation?

As an appetiser we will firstly consider his development of a full-blown Western contextual theology. This includes his view of the relationship between "liberation" and "emancipation". In the section thereafter we will scrutinise the core of his theology: Christology; it will become apparent that Christology binds together all the essential aspects of theology. In the third and final section the implications of Schillebeeckx's theology of liberation in our South African context with regard to anthropology and creation will be expounded; we will also evaluate the theological contribution of Edward Schillebeeckx. 
We will not discuss the historical development of Schillebeeckx's thought, but his ideas will be synthesised and used as a tool to scrutinise our own situation. It will be done in a critical fashion to distinguish between the wheat and the chaff. The aim of this article is not to supply easymade answers, but to provoke lively discussion and to stimulate further thought and action.

\section{3}

\section{LIBERATION THEOLOGY IN THE NETHERLANDS?}

It is common knowledge that there are different prevailing types of political theologies in Europe. Schillebeeckx is nevertheless the first theologian of the First World with the audacity to call his own theology a "theology of liberation" without provoking protest from Latin-American and African theologians. G Gutierrez, the renowned Latin American theologian, has voiced his high regard for the dialogical relationship between church and world which Schillebeeckx advocates in sharp contrast to the earlier "monologue" of the church as if the world has no voice of its own'.

It is important to note that the intention of building a theology of liberation is not a "recent interest" as one of his renowned pupils described his thought ${ }^{3}$. According to Schillebeeckx, this interest has for a long while been deeply imbedded in his theology as the leading theme ${ }^{4}$. It has been running like a golden thread throughout his theology since 1968 .

This "interesse" was cultivated by a thorough study of, on the one hand, Neo-Marxism which led him to J Habermas and his critical sociology as 'n way of dismantling ideologies 5 ; and, on the other hand, by a critical historical and literary study of the New Testament to examine the relationship between liberation as 'n biblical reality and the need of modern man for emancipation on all different levels of life (cf his Christological trilogy) ${ }^{6}$. He synthesised his thought into an ecumenical and pastoral fundamental theology which addresses the basic questions of men and women in Europe, but also cross-culturally in the rest of the world?

In concrete terms this meant practising theology in a new modus and with a different interest. In opposition to the classical "Roman" theologians, Schillebeeckx's theology is not aimed at preserving the Catholic Church institutionally and therefore apologetically. To him theology has become hermeneutics of Christian praxis ${ }^{8}$. The function of theology is to ascertain whether the praxis of the church is secundam scripturas. Praxis is therefore always the precursor of theology. He regards theory as a function of the Christian praxis?. Orthopiaxy moves even more to the forefront as a criterion in his theology than orthodoxy, when he writes that the choice in the struggle between right and wrong, between oppressors and oppressed, is more vital than the confessing of God ${ }^{10}$.

According to Schillebeeckx hermeneutics does not only entail better 
understanding of the cosmos, but it is indeed an instrument of renewal of creation in the dialectical tension between history and eschatology. The problem of our modern history of liberation is the problem of emancipation on a new horizon of understanding and praxis ${ }^{11}$. "The basic hermeneutic problem of theology, then, is not so much the question of the relationship between the past (scripture and tradition) and the present, but between theory and practice, and this relationship can no longer be solved idealistically, by a theory of Kantian pure reason from which consequences flow for the practical reason, but it will have to be shown how the theory appears in the praxis itself. How, for example, can religious freedom, as formulated by Vatican II, be deduced by purely theoretical exegesis from the church's past? The church's practice in the past at least contradicts this theory rather seriously. Only a new praxis in the church can make the new interpretation credible..."12.

The problem, however, still remains: Can a modern, white priest, living in a privileged society, steeped in the Western academic tradition and professor of doctoral students only, have any credibility propounding a theology of liberation?

The answer lies in the first instance in the self-critical attitude of Schillebeeckx. He regards the question of the position of the theologian in the university, the churches, the congregations on grassroots-level and in daily life as urgent. The theologian must take cognisance of the objective society in which he finds himself, as well as of the academic-scientific tradition within which he operates. The power-structures in the church and the society must be critically analysed. This is the way in which he tries to overcome the problem of creating new ideologies ${ }^{13}$. The context in which he practises his theology, is in the first instance the context of world-poverty. In this situation the universal gospel obtains a new social dimension ${ }^{14}$.

The second reason why Schillebeeckx has integrity in the circles of the churches and theologians in the so-called Third World, is the fact that he regards the experience of suffering mankind as the concrete starting point of his theology, not one or the other theory or formula ${ }^{15}$. Furthermore, the theological method of Schillebeeckx, especially his focus on praxis, is acceptable to them. His experiencebased theology is far removed from the Western scholastic theology 16 .

Praxis is the main task of the critical theory, which became the basis for his writings on church and world, on ethics and ministry. Iwashima pointed out the important results of this hermeneutical viewpoint: "Die Folge ist nicht gering: Die Berücksichtigung der Praxis bei der Glaubensinterpretation holt die theologische Hermeneutik aus dem geschlossenen Kreis der 'Ideengeschichte' heraus und setzt sie in die Realgeschichte hinein"17.

Schillebeeckx's viewpoint of the meaning of "emancipative praxis" is explained by Schreiter as follows: "More than the theoretical understanding of 
hermeneutical theology, this approach calls for a liberating of consciousness from a false understanding (ideology) which in turn calls for contesting the dominant view of society"18.

Schillebeeckx's history of intercession on behalf of the Latin-American Christians, especially his concern on the eve of the historical Puebla-conference, will not be lightly forgotten 19 .

Western critique which does not acknowledge the evangelical inspiration of the Latin American theology is discarded by Schillebeeckx ${ }^{20}$. Even so, he puts his own critical questions to the theology of liberation. It is especially the identification of the church with the class-struggle which is a travesty of the gospel. No social class can, in the light of the universality of God's grace, be regarded as the universal subject and torch-bearer of the meaning of history ${ }^{21}$. He criticises the political theology of J.B.Metz on the grounds that it implies that the suffering person is the "universal subject" of history 22 .

According to Schillebeeckx Marxism is not the best instrument of practising solidarity with the poor. Critical-sociological results made it clear that other ways of analysing society are more fruitful 23 .

\section{4 \\ CHRISTOLOGY AS CONCENTRATED CREATION}

Schillebeeckx defines Christology as "concentrated creation". This is without doubt his most radical and fundamental statement on Christology. The first two articles of the Apostolicum is thereby linked and the second is placed in the circumference of the first. Christology as "concentrated creation" means that God, by revealing Himself as the Creator, the God of humans, loves us without any condition or merit from our side. The concentration of creation in Christ also points to the finality of the redemptive work of God in Jesus of Nazareth. Christ is love made flesh. "That is why Christology is creation, concentrated and condensed: faith in creation as God wishes it to be"24.

The actual history of humanity frustrated the promise of creation. Nevertheless, God fulfills this promise by installing his reign of peace. "Israels oude droom van het komende rijk als sjaloom voor mensen, 'in handen van de mens gelegd', is dan ook de verwachtings- en ervarings-horizon waarbinnen Jezus gezien en geinterpreteerd moet worden, de mens in wie de scheppingsopdracht is geslaagd, zij het nog binnen de condities van een lijdensgeschiedenis"25. In a dialectical fashion Schillebeeckx can maintain on the one hand, that salvation is not our own doing, and on the other hand, in our history the future of God is being decided ${ }^{26}$.

Schillebeeckx describes Jesus as concentrated creation because it highlights the unique place of Jesus in God's redemptive plan and acts. Irenaeus' definition is almost programmatic for Schillebeeckx to describe the relationship 
between God and man: "Gloria Dei, vivens homo. Vita autem hominis, visio Dei"27. Faith in this man, Jesus, is concretization of our faith in God as Creator 28.

In Jesus creation and eschatology are one. He is the alpha and the omega. The covenant is fulfilled in His person 29 . In the Old Testament the wonders of creation are being exalted in the framework of the Exodus. In the light of this, liberating yourself is a command given by our Creator which encompasses our whole life. In this way the Western dualism between church and world, reason and faith is superseded. "In de christelijke beleving heeft men vaak de eenheid van schepping en verbond verbroken. De Schepper zelf is de Verlosser en zelfs in zijn verlossende activiteit treedt Hij goddelijk op, d.i. per definitie scheppend, derhalve zonder dat er rivaliteit bestaat tussen wat $\mathrm{Hij}$ doet en wat wij, gegrond in $\mathrm{Hem}$, zelf doen"30.

Jesus' experience of God as "Abba" is the experience of God as the Power of the future, redeeming us through love. This is interconnected with creation. In the Jewish tradition creation means io "rebuild that which was broken"31.

Creation, salvation and the completion of creation depend on Christ. There is no historical pattern of creation, fall and redemption. Creation is a free gift of God. Human frailty is not sin and God does not want to save us from transience. He does, however, want to be our God in all transitoriness 32 .

The relationship between Christology and anthropology is of vital importance in Schillebeeckx's creation theology. Theology is not anthropology, according to him, but every theological statement is also an anthropological statement ${ }^{33}$. The acknowledgement of God as God is simultaneously the recognition of the humanity of $\operatorname{man}^{34}$. For Jesus the reign of God is not a concept or a doctrine, but an experience of reality 35 . God's plan with humanity was revealed in Jesus ${ }^{36}$. Living man is the fundamental symbol of God: the image of God ${ }^{37}$ (T:69). Not only man's spirit is made in God's image. Man is spirit-embodied in a substantial unity, albeit unity is not monism. Man differs from even the most complex other living creatures: liberty and thought constitute man and woman as humans ${ }^{38}$.

According to M C Hilkert, an excellent interpreter of Schillebeeckx's theology, the central scope of his theological project is the negative contrast experiences of humanity 39 . This experience calls for decisive praxis. Rather than choosing one or the other anthropological model, Schillebeeckx opts for the one aspect which is present in all different anthropologies: the negative experience of suffering. His negative starting point helps to analyse and identify underlying ideologies which are detrimental to human well-being. "Heil en menselijkheid, heilzijn, integriteit op waarlijk menselijk-vrije wijze is juist het thema van heel het verhaal van de mens"40. It cautions man again associating too easily or fully with one or the other party or class, because the Name of God and Jesus Christ can be misused by oppressors as well as freedom fighters ${ }^{41}$. For this reason, it is of the 
utmost importance that all different political policies in the South African society must be examined in the light of the reign of God. Every ideology which is harmful to human freedom and well-being, must be unmasked.

The Christian norms which Schillebeeckx believes must be built anew, are not a mere restatement of the norms which were used in New Testament times. On the basis of his historical hermeneutics he uses the concept of historical mediation to define norms for our own situation which has the same function and goal as the norms functioning in the first Christian community: the furtherance of the reign of God. These norms must be cultivated through a critical consciousness in which the critical rationality must be selfcritical ${ }^{42}$.

He discerns seven anthropological constant elements(in contradistinction to a positivist, philosophical or marxist definition of true humanity) which he sees as secure values. These values must be concretized anew by creating new norms in our dynamic historically changing process. In the light of these values, different norms can be shaped which will ensure that humans, their culture and society are not disgraced and hurt. In this way human dignity and well-being are being enhanced.

The seven constant elements are the following: (1) The relationship to our human corporeality, nature and our ecological milieu; (2) Humanity as co-humanity; (3) Our relation to societal and institutional structures; (4) Time and space structure of person as well as culture; (5) The correct relationship between theory and praxis; (6) The religious and para-religious consciousness of humanity; (7) Synthesis of all six dimensions as necessary prerequisite for human well-being ${ }^{43}$.

History and culture are both dynamic realities which function throughout in his anthropology. Culture is an integral part of humanity. The return to a natural, non-cultural brotherhood advocated by the Aufklärung is dismissed by Schillebeeckx as unreal and without any substance, because it still leaves the outcasts in the cold 44 .

\section{IMPLICATIONS FOR ANTHROPOLOGY AND CREATION IN THE SOUTH AFRICAN CONTEXT}

\subsection{Christian anthropology}

The nature of the problem of our South African situation is anthropological45. The anthropology of Schillebeeckx can help us to see underlying causes of the malaise of our country. It is by no means our intention to follow the footsteps of humanism in the process of analysing the anthropology of Schillebeeckx. We are not talking about man in an abstract and idealistic fashion, but as man coram Deo. In this context the whole creaturely reality of man is acknowledged ${ }^{46}$. Schillebeeckx states emphatically that religion is an anthropological constant element and every 
liberation which does not include religious salvation, can be only partial liberation. If such a liberation occurs in the guise of total liberation, it diminishes a real dimension of our humanity and works destructively rather than furthering liberation ${ }^{47}$.

\section{$5.2 \quad$ Ideologies}

For the past forty years we have lived in a society where ethnicity was regarded as the most important aspect of mankind. This was, anthropologically speaking, the most fundamental ideological thought-pattern which was instilled in people's minds, consciously and subconsciously. Structurally this idea was embodied in laws as well as the attitudes of society. The General Synod of the Dutch Reformed Church of 1990 described apartheid as an ideology which is discriminatory and racist. The Synod also confessed its guilt for not protesting much earlier against the theological defense of apartheid ${ }^{48}$.

For Schillebeeckx, the problem of South Africa lies in the existence of what he calls "the non-person, the poor and downtrodden" in a country which has been ruled by Christians for centuries. This is a source of vexation for every Christian, he says. As a result of this discrimination our faith loses credibility with many modern people ${ }^{49}$.

Our South African society was also ruled, to a higher or lesser degree, by economic laws. Materialism is a way of life for many of the rich and idealised by many of the poor. This explains the high incidence of corruption throughout society.

According to Schillebeeckx, the problem with the political reasoning of mankind is not in the first instance the wickedness of man or his struggle for power, but the structural influences of a system of values in which neither political reason nor the "humanum" has the priority, but the economy. "De vraag is, of niet de door collega Kuitert erkende evidente noodsituaties byvoorbeeld in Zuid-Afrika en Latijns-Amerika wezenlijk en structureel ook te maken hebben met wat in onze westerse democratiën en welvaartsstaten gaande is, zodat de spanningen o.m. tussen de noord en zuid-as en de oost en west-as, alsook de fundamenteel triestige, mondiale verschillen in verdelende rechtvaardigheid van de materiële en geestelijke goederen en van arbeid, de hedendaagse politieke wereld in breedte en lengte, in hoogte en diepte tot een grootse noodsituatie maken. Hoewel ik als gelovige vertrouwen schenk aan het gebruik van de politieke rede in een democratisch bestel, toch moet ik als kritisch gelovige de wetten doorzien waardoor in een wereldbestel van prioriteit van economische en vaak ook militaire belangen, de politieke rede gemanipuleerd wordt en ideologisch gaat functioneren"50. This viewpoint of Schillebeeckx is important because of the clear criterion and value which he underscores: the human person. In our society and our churches this value 
must also be emphasized from a Christological perspective ${ }^{51}$. The well-being of humans may not be sacrificed to economic or military "priorities".

\section{$5.3 \quad$ The poor and oppressed}

In our situation in the changing South Africa, the light of the Christian values will have to be carried to all levels of society through the praxis of the Christian churches. Schillebeeckx exhorts us to live according to the praxis of the reign of God in solidarity with all people, and as such, in a partisan choice for the poor and oppressed. This implies taking a stand against the oppression by the powerful and by structures which are dehumanising 52 . This demand will require much of the different churches, especially the Dutch Reformed Church, because of its social setting and history. However, this church has accepted the call to justice and love. In the church's "witness" this principle is underscored. Sensitivity for the oppressed and downtrodden is called a biblical principle which must be applied in our own society 53 .

We should sound a warning signal at this point because of certain tendencies in the ecumenical theology of Schillebeeckx in which the truth of our confession is made a secondary reality to siding with the oppressed. In this way ortopraxy and orthodoxy are torn apart while they are intrinsically one reality.

Becoming a church of hope for all will be realised only if the Reformed Churches of Southern Africa unite and form a single body as members of Christ. Ecumenical initiative from local congregations are of the utmost importance to attain this goal. Different structures are possible to accommodate different cultures in one church. Problems regarding theology, the relationship of faith and culture (Western or African) should be discussed in the light of our common confession of Jesus as Lord over all principalities and powers.

In our society the problems of the poor are the responsibility of the whole nation. Schillebeeckx warns against neglecting our social responsibility through a false trust in our eschatological hope ${ }^{54}$. The churches may not be divided as to which anthropological model to use 55 . In the light of the teaching of Scripture we must act upon the needs of our society. Alleviating poverty and everything it entails must be seen as a calling of God. The "negative contrast experience" of which Schillebeeckx speaks can be used as starting point for ecumenical discussion and action.

\subsection{Anthropology and creation}

The last constant element in Schillebeeckx's anthropological co-ordination system is the most important of the seven elements and an important contribution in the 
theological debate on anthropology. The implications for our theme is made explicit in the following quotation: "Christelijk heil...heeft dus te maken met hél het coördinatensysteem waarin de mens waarlijk mens kan zijn. Men kan dit heil- hélzijn van mensen - niet zoeken in slechts de ene of de andere van deze constanten, bv. in uitsluitend 'ecologische creten', in uitsluitend 'lief zijn voor elkaar', in uitsluitende omverwerping van een economisch bestel (marxistisch of capitalistisch) of in uitsluitend mystieke ervaringen: "halleluia! Hij is verrezen! Anderzijds is de synthese van dit alles een duidelijk 'al-reeds' en 'nog-niet"'56.

The significance of his theology for creation as a whole is his appreciation for technology and science as instruments of enhancing human well-being. However, he also warns against a total trust in science and technology and the ideal of technocratic control over nature. "Niet de wetenschap of techniek met hun mensbevorderende mogelijkheden staan aldus onder kritiek, wel vaak hun impliciete vooronderstellingen"57.

On the modern cultural horizon modernity is the dominant impulse. It produced two negative results: the technological and bureaucratic West caused a deficit of experience, and the unlimited freedom and human rights have become oppressive and repressive in itself. In a "post-modern" sense the new values of modernity must be made fruitful so that freedom will be closely related to solidarity with all people, especially those who are not free ${ }^{58}$.

\section{$5.5 \quad$ Violence}

In our situation of uncontrollable violence the churches are called to witness that God is the mystery of all-encompassing love ${ }^{59}$. Jesus brought God back in the experience of mankind 60 . This is especially true in God's way of liberation. Jesus' liberation is a way of suffering, not a way with weapons of injustice. "Jezus kiest voor de verlossende en bevrijdende liefde, die wel niet onmiddelijk ontwapenend is en de ander tot inkeer brengt-integendeel vaak-, maar 'desondanks' zal de liefde het uiteindelijk halen op geweld"61.

The church is not in itself the kingdom of God. The ecclesiology of Schillebeeckx is the bond between his anthropology and his view of creation. The church is the sacrament (a sign which is being effectuated) of the oneness or communio of the whole of humanity through its oneness with the living God 62 . Schillebeeckx states that Jesus left us a living community of believers. "Niet een heilige rest, maar eerstelingen van de verzameling van hél Israel, en ten slotte van heel het mensdom. Met andere woorden: een eschatologische bevrijdingsbeweging, met als doel álle mensen te verzamelen en tot eenheid te brengen, tot vrede: onderling, 
met elkaar en alle volkeren, èn met de natuur. En dit alles op grond van de eenheid met de levende God" 63 . The role of the church as agent of peace and reconciliation is therefore of the utmost importance.

To Schillebeeckx the centre of all salvation is justification through grace. All other aspects of liberation are highlighted and seen in perspective from this viewpoint 64 . Liberation and reconciliation is closely related.

This is exemplified in the history of reconciliation of Jacob and Esau (Gen 32:25-32). This is of great significance, especially to black and white estranged "brothers in Christ" in South Africa. Jacob is changed radically in his encounter with God during the night, and as a new man he confronts his brother. "In het elkaar wederzijds aanvaarden en bevestigen in een persoonlijke, verzoenende ontmoeting van Jakob en Esau, licht het aangezicht van God zelf op...Op het gelaat van verzoende mensen straalt als de zon het eigen gelaat van God. Daarom noemde Jakob de plaats Peniël, d.i. 'aanschijn van God', want 'ik heb God gezien van aanschijn tot aanschijn en ik mocht leven... Verzoenden hebben bestaansrecht, het recht om te leven. Verzoening is leven, mógen leven. Zij maakt ons leven, binnen onze geschiedenis van lijden en onrecht, de moeite om te leven waard"65.

CONCLUSION

This article illustrates the central scope of Edward Schillebeeckx's contextual theology. He believes that the relevance of theology depends on the churches' ability to draw the line from liberation to salvation. Schillebeeckx's liberation theology is a bridge between the theologies of the First and the Third World and is critical both to Marxist thought and to Western economic values. It is primarily his Christology which provides him with a clear view of anthropology and creation and highlights the church's role in the process of reconciliation and renewal. It is especially his antropological co-ordinates which can serve as a basis of ecumenical discourse in our South African context.

The implications of his theology for our own situation is clear. It demands a critical attitude towards our values. By implementing a historical hermeneutics, he challenges us to respond to the problems of our post-modern age. In thought and action the Christians must be in the forefront, proclaiming God's rule as liberating to men and women everywhere, especially to the sick, the poor and the needy. In our post-apartheid era we will have to learn to communicate anew and to experience the love of Christ which transcends cultural and political differences. The true opposite to an ideology of separation is not a new ideology of unity (where everyone still fends for himself), but the gospel of peace, communion and grace. The implication of such an attitude is concern for the needy and taking responsibility to act on one another's behalf. This implies also the restoration of the 
value of the human person in its totality. He highlights again the danger of the negligence of the religious dimension of being human by including it as one of the basic elements of humanity.

\section{NOTES:}

1 This article was delivered as a paper at the Theological Society of Southern Africa at its meeting in Pietermaritzburg, July 1991.

2 G Gutierrez, "Twee perspectieven op de kerk" in: H Häring, T Schoof, A Willems (eds) Meedenken met Edward Schillebeeckx (bij zijn afscheid als hoogleraar te Nijmegen), Baarn 1982, 224.

3 R J Schreiter, Edward Schillebeeckx: His Continuing Significance, in: R J Schreiter and M C Hilkert (eds) Praxis of Christian Experience, San Francisco $1989,151$.

4 E Schillebeeckx, Mensen als verhaal van God, Baarn 1989, 188.

5 E Schillebeeckx, Geloofsverstaan: Interpretatie en kritiek, Teologiese Peilingen deel 5, Nelissen 1972, 164-208.

6 E Schillebeeckx, Jezus, het verhaal van een levende, Bloemendaal 41975; Gerechtigheid en liefde, genade en bevrijding. Bloemendaal 1977, a w, 1989.

7 D J Malan, Die funksie van die metodiek in die Christologie ,'n Ondersoek aan die hand van E Schillebeeckx se Jesus-boeke, ongepubliseerde D Thproefskrif, Stellenbosch 1990, 169-210.

$8 \quad$ E Schillebeeckx, "Het kritisch statuut van de theologie", in: De toekomst van de kerk, verslag van het wereldcongres Concilium te Brussel 12-17 September 1970, Amersfoort 1970b, 64.

9 E Schillebeeckx, Kerkelijk ambt, Voorgangers in de gemeente van Jezus Christus, Bloemendaal 1980, 116.

10 Schillebeeckx, $a w, 1989,27$.

11 Schillebeeckx, $a w, 1975,545 ; a w, 1977,752$; cf also his important lectures: Als politiek niet alles is. Jezus in de westerse cultuur, Abraham Kuyperlezingen, Baarn 1986, 32 on the correct approach to theology.

12 E Schillebeeckx, The Schillebeeckx reader, R J Schreiter (ed), Edinburgh 1986, 116.

13 E Schillebeeckx, Theologisch geloofsverstaan anno 1983, afscheidscollege gegeven op vrijdag 11 Februari 1983 door Mag dr Edward Schillebeeckx O P (Januari 1958 - 1 September 1982), Baarn 1983, 4-5.

14 Schillebeeckx, $a$ w, 1989, 188. 
15 J P Galvin, "Retelling the Story of Jesus: Christology" in: R J Schreiter and M C Hilkert (eds), The Praxis of Christian Experience, San Francisko 1989, 5267.

16 Cf E L Krasevac, Revelation and experience: An analysis of the Theology of George Tyrrell, Karl Rahner, Edward Schillebeeckx, and Thomas Aquinas, Ph D The Graduate Theological Union, Berkeley, 1986. Krasevac stresses the intimate connection between revelation and experience in the theology of Schillebeeckx.

17 T Iwashima, Menschheitsgeschichte und Heilserfahınng, Düsseldorf 1982, 374.

18 Schreiter, $a w, 1986,107$.

19 E Schillebeeckx, Bevrijdingstheologieën tussen Medellin en Puebla (Dies-rede) Nijmegen 1978, 3.

20 Schillebeeckx, $a$ w, 1977, 699.

21 Schillebeeckx, $a w, 1978 \mathrm{~b}, 14$.

22 Schillebeeckx, $a w, 1977,694-696$.

23 Schillebeeckx $a w, 1977,726 ; a w, 1986,73$.

24 E Schillebeeckx, "A Creative Retrospect as Inspiration for the Ministry in the Future", in: Minister/Pastor? Prophet? London 1980a, 20

25 E Schillebeeckx, Tussentijds verhaal over twee Jezus boeken, Bloemendaal 1978a, 126.

26 Cf Schillebeeckx's critique of the pioneering work of Gustavo Gutierrez in J Bowden, Edward Schillebeeckx portret van een theoloog, Baarn, 1984, 128. John Bowden describes Schillebeeckx's reaction as follows: "Omdat Gutierrez de bevrijding primair als een lovenswaardige inspanning van mensen ziet, komt bij hem de genade Gods op het tweede plan. Schillebeeckx acht dit een al te dualistische stelling. Hij voert aan dat de genade daadwerkelijk in het bevrijdende handelen geschiedt. Hij wijst erop dat in het Nieuwe Testament de genade niet ten overstaan van de natuur of van de schepping optreedt, maar ten overstaan van zondaren en sloeberts werksaam is".

27 Schillebeeckx, $a w, 1977,728,742$.

28 Schillebeeckx, $a w, 1978 \mathrm{a}, 127$.

29 Ibid, 125.

30 Schillebeeckx $a$ w, 1977, 704, 705.

31 Schillebeeckx, $a w, 1975,220$. 
32 Schillebeeckx, $a w, 1978 \mathrm{a}, 131$.

33 Schillebeeckx $a$ w, 1977, 48, 49.

34 Schillebeeckx, $a w, 1975,513$

35 Ibid, 116.

$36 \quad$ Jbid, 493.

$37 \quad$ Schillebeeckx $a$ w, 1978a, 69.

38 E Schillebeeckx, "De grens tussen leven en dood", Kultuurleven 37 (1970a), 119-126.

39 M C Hilkert, Towards a theology of proclamation: Edward Schillebeeckx's hermeneutics as a foundation for a theology of proclamation, Ph D The Catholic University of America, Michigan 1984, 186, 187.

40 Schillebeeckx, $a$ w, 1977, 673.

41 Schillebeeckx, $a w, 1989,30$.

42 Schillebeeckx $a$ w, 1977, 673.

$43 \quad$ Ibid, 674 and further.

44 Schillebeeckx, a w, 1975, 484, 485.

45 J Kinghorn, "Teologie en sosiaal-antropologie" in: P F Theron en J Kinghorn (reds) Koninkryk, kerk en kosmos (Huldigingsbundel aangebied aan prof W D Jonker op sy sestigste verjaarsdag), Bloemfontein 1989, 112-129.

46 G C Berkouwer, De mens het beeld Gods, Kampen 1957, 213.

47 Schillebeeckx, $a$ w, 1977, 681.

$48 \quad$ Kerk en samelewing, ' $n$ Getuienis van die Nederduitse Gereformeerde Kerk, Oktober 1990, 38-40. Cf also: D J Malan, "Pastorale sensitiwiteit: Die Kerk se rol in die nuwe Suid-Afrika" in: Fokus op die kerk, S J Joubert en P G J Meiring (reds), Vereeniging 1992, 117-119.

49 Schillebeeckx, $a w, 1989,73$.

50 Schillebeeckx, $a$ w, 1986, 77; cf also H M Kuitert, Alles is politiek, maar politiek is niet alles, Baarn 1985.

51 D A du Toit, Die mens en sy regte, Kaapstad 1988, 69, 73.

52 Schillebeeckx, $a w, 1989,50$.

53 Kerk en Samelewing, 22,23. 
$54 \quad$ Schillebeeckx, $a w, 1989,73$.

55 For a discussion on anthropological models, of A König, "Rykdom in verskeidenheid: 'n poging tot 'n ekumeniese antropologie" in: $C \mathrm{~J}$ Wethmar en C J A Vos (reds) ' $n$ Woord op sy tyd (Feesbundel aangebied aan prof J A Heyns met sy sestigste verjaarsdag), Pretoria 1988, $79-87$.

56 Schillebeeckx, a w, 1977, 683.

$57 \quad$ Ibid, 676.

58 Schillebeeckx, $a w, 1989,71,72$.

$59 \quad$ Ibid, 151.

60 Schillebeeckx, $a$ w, 1977, 469.

61 Ibid, 637, 638.

62 E Schillebeeckx, "Het leed der ervaring van Gods verborgenheid", Vox Theologia 36 (1966), 92-104.

63 Schillebeeckx, $a$ w, 1989, 176.

64 Schillebeeckx, $a w, 1977,770$.

65 Ibid, 701-703. 